\title{
REGRESSION MODELS OF INDIVIDUAL CEPHALOMETRIC PARAMETERS IN UKRAINIAN YOUNG MEN AND YOUNG WOMEN WITH DIFFERENT FACIAL PROFILES ACCORDING TO SCHWARZ A.M., WHICH CAN BE ADJUSTED DURING SURGERY DEPENDING ON THE PARAMETERS THAT USUALLY DO NOT CHANGE
}

\author{
National Pirogov Memorial Medical University, Vinnytsya, Ukraine
}

\section{Relevance}

The method of lateral teleroentgenography is an extremely valuable, informative and accessible method of radiological research in dentistry and allows us to obtain qualitative standardized images and obtain important quantitative characteristics of both bone cranial and gnatic structures of the patient and qualitative and quantitative indicators of facial soft tissues $[6,17,18,20]$. Practitioners use in their work a variety of methods of cephalometric analysis, the most common and popular of which, including in Ukraine, are the methods of Steiner, Schwarz, Ricketts, Jaraback, Burstone, Bjork, Harvold, Tweed's, Down's, McNamara, guided by subjective criteria. The vast majority of author's methods developed in the middle of the 20th century, to some extent differ in the indicators recommended by the authors, and the values of the indicators themselves, given as standards, obtained from different contingents of the population of different countries. At the same time, subsequent studies have shown the presence in a number of cases of pronounced differences in the values of these indicators in humans, depending on their race, ethnicity, population $[7,8,21,22]$. In addition, after a certain stage of accumulation of factual material, in our opinion, it is extremely important not only to determine the limits of normative values of cranio- and gnatometric indicators of teleroentgenograms but also to model appropriate indicators characteristic of certain groups of the population. This is logical, the numerous publications on the presence of correlations between different cephalometric indicators, both foreign $[5,11,15]$ and domestic researchers [1, 4] are given.

The aim of the work is to build and analyze regression models of tele- teleroentgenographic indicators, which can be adjusted during surgery depending on the parameters that usually do not change in Ukrainian young men and young women with different facial profiles according to Schwarz A. M. with normal occlusion close to orthognathic occlusion and a harmonious face.

\section{Materials and methods}

Lateral teleroentgenograms of the head were obtained in 49 young men aged from 17 to 21 years old and 76 young women aged from 16 to 20 years old with a physiological bite as close as possible to the orthognathic (hereinafter orthognathic bite) using a dental cone-beam tomograph Veraviewepocs 3D Morita. Part of the primary teleroentgenographic indicators was obtained from the database of lateral teleroentgenograms of the research center of $\mathrm{Na}$ tional Pirogov Memorial Medical University, Vinnytsya. Young men and young women were divided into separate groups with different facial profiles according to the recommendations of Schwarz A. M. [25] (Table 1). Quantitative distribution of young men and young women groups with different facial profiles.

Table 1.

\begin{tabular}{|l|c|c|c|}
\hline \multicolumn{1}{|c|}{ Research groups } & By Schwarz A. M. & Juvenile men & Juvenile women \\
\hline 1 face profile & back face profile & 23 & $\mathbf{3 7}$ \\
\hline 2 face profile & straight face profile & 9 & $\mathbf{1 5}$ \\
\hline 3 face profile & front face profile & 17 & $\mathbf{2 4}$ \\
\hline
\end{tabular}

The analysis of teleroentgenographic indicators was performed by licensed medical software. Measurements were performed according to the recommendations of Schwarz A. M. [25, 26]. Cephalometric points were determined in accordance with the recommendations of Phulari B.S. [23] and Doroshenko S. I. and Kulginsky E. A. [3].

Indicators in this study were divided into two groups [2]. The first group includes metric characteristics of the skull used in the methods of Bjork A. [9],
Burstone C. J. [10], Jarabak J. R. [19], Ricketts, R. M. [24], Schwarz A. M. [25, 26] and Stainer C. C. [27] and which usually is not changed during surgical and orthodontic treatment, but they are used as basic indicators in the methods of cephalometric analysis. Relative to these indicators on the lateral teleroentgenograms determine the slope, anterior-posterior or vertical position of the gnatic structures (upper and lower jaws, the closing plane and individual teeth). The second group of indicators - dental-jaw indicators accord- 
ing to the method of Schwarz A. M. [25, 26], the definition of which is most often used during orthodontic surgery in children, adolescents and youth, as well as in adults with bone the skeleton has already been formed and what surgical methods can be used to change the length, width, angles and position of the upper and lower jaws.

According to the cephalometric method of Schwarz A. M. [25, 26], the following indicators of the second group were modeled depending on the indicators of the first group (Fig. 1): distance Max (length of the upper jaw) - distance from the constructive point apMax to the point PNS (mm); angle F (front angle) is formed by lines Se-N and N-A and determines the location of the anterior contour of the upper jaw in the boom plane to the base of the skull ( ${ }^{\circ}$ ); angle I (inclination angle) - determines the angle of inclination of the upper jaw (spinal plane) to the nasal perpendicu$\operatorname{lar}\left({ }^{\circ}\right)$; distance L_Mand (length of mandible) - length of the mandible (distance from the projection of the Pog point on the line tGo-Me to the point tGo) (mm); angle $G$ (gonial angle, angle of the mandible) - is formed by the lines ppCond-MT2 and T2-Me, which intersect at the point tGoS $\left(^{\circ}\right.$ ); distance R.asc. (length of the mandibular branch) - the distance from the design point R.asc to the design point tGoS $(\mathrm{mm})$; angle $B$ (basal angle) - indicates the angle between the upper and lower jaws ((formed by the lines ANS-PNS (palatal plane $\mathrm{SpP}$ ) and Im-Me (mandibular plane MPS according to Schwarz)) $\left({ }^{\circ}\right.$ ); angle MM (maxillary mandibular angle) - you define the angle at which the upper jaw is located relative to the lower jaw in the sagittal plane (formed by lines AB and ANS-PNS) $\left({ }^{\circ}\right.$ ); angle $T$ (profile angle $T$ ) - formed by lines Sn-Pog' and $\mathrm{Pn}$ (nasal perpendicular) $\left({ }^{\circ}\right.$ ).

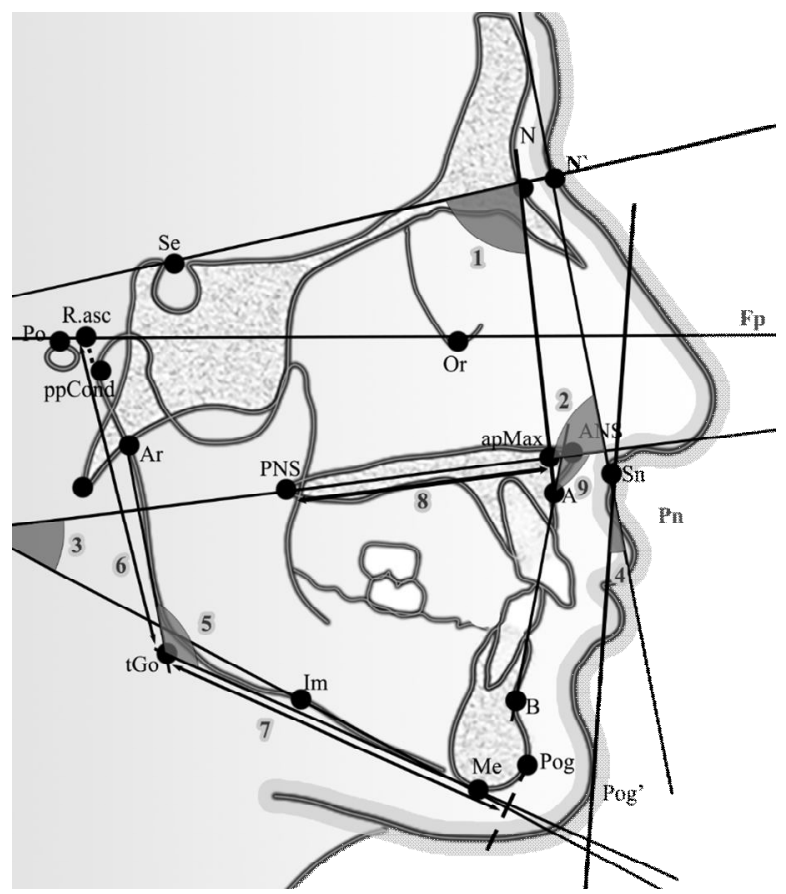

Fig. 1. Teleroentgenographic indicators of the upper and lower jaws, which most often change during surgery and orthodontic interventions:

1 - angle $F ; 2$ - angle I; 3 - angle $B ; 4$ - angle $T ; 5$ -

angle G; 6-distance R.asc.; 7 - distance L_Mand; 8 - distance Max; 9 - angle MM.
Regression models of individual teleroentgenographic indicators are built in the license package "Statistica 6.0".

\section{Research results and their discussion}

The results of cephalometric parameters modeling, which can be adjusted during orthodontic and surgical interventions depending on the basic parameters in young men and young women with different facial profiles according to Schwarz A. M., have the form of the following linear equations.

For young men with 1 face profile:

$B$ (young men profile 1) $=0,761-0,945 \times$ ar-Go $+0,894 \times \mathrm{H}-4,477 \times \mathrm{N}-\mathrm{S}: \mathrm{S}-\mathrm{Ar}^{\prime} \quad\left(\mathrm{R}^{2}=0,642 ;\right.$ $F_{(3,19)}=11,36 ; p<0,0002$; Error of estimate $\left.=3,651\right)$;

G (young men profile 1) $=170,3-1,119 \times$ ar-Go $+0,787 \times \mathrm{H}-4,620 \times \mathrm{N}-\mathrm{S}: \mathrm{S}-\mathrm{Ar}^{\prime}-0,766 \times \mathrm{N}-\mathrm{Se}$ $\left(R^{2}=0,742 ; \quad F_{(4,18)}=12,94 ; p<0,0000\right.$; Error of estimate=3,712);

R.asc. (young men profile 1 ) $=-39,15+0,789$ $\times$ ar-Go $+0,617 \times \mathrm{POr}-\mathrm{NBa}+1,102 \times \mathrm{N}-\mathrm{Se}-0,489$ $\times \mathrm{N}-\mathrm{CC}\left(\mathrm{R}^{2}=0,870 ; \mathrm{F}_{(4,18)}=30,11 ; p<0,0000\right.$; Error of estimate $=1,814)$;

where here and hereafter, $R^{2}$ is the coefficient of

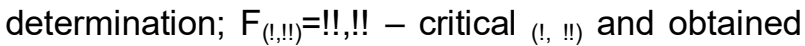
(!!, !!) value of Fisher's criterion; St. Error of estimate - standard error of the standardized regression coefficient; ar-Go (length of the lower jaw branch according to Burstone C. J.) - the distance from the point $\mathrm{Ar}$ to the point $\mathrm{Go}(\mathrm{mm}) ; \mathrm{H}$ (angle $\mathrm{H}$ according to Schwarz A. M.) - the angle formed by the lines $\mathrm{Po}-\mathrm{Or}$ and $\mathrm{Pn}$, determines the angle of inclination of the Frankfurt plane to the base of the skull $\left({ }^{\circ}\right.$ ); N-CC (anterior length of the skull base according to Ricketts R. M.) - the distance from the point $\mathrm{N}$ to the point $\mathrm{CC}(\mathrm{mm})$; N-S:S-Ar (indicator $\mathrm{N}-\mathrm{S}$ :S-Ar' according to Bjork A.) - indicator of the ratio of distances ar'-S and N-S; N-Se (length of the anterior part of the skull base according to Schwarz A. M.) - the distance from the point Se to the point $\mathrm{N}(\mathrm{mm})$; POr-NBa (cranial tilt (deflection) angle according to Ricketts R. M.) - the angle formed by the lines $\mathrm{Po}-\mathrm{Or}$ and $\mathrm{Ba}-\mathrm{N}\left({ }^{\circ}\right)$.

In young men with 1 facial profile, the coefficients of determination of the regression equations of the distances L_Mand and Max, as well as the angles MM, F, I and T were from 0.197 to 0.599 and therefore have no practical significance for orthodontists.

For young men with 2 face profile:

L_Mand (young men profile 2) $=56,36+1,693 \times$ S-E - 0,428 x POr-NBa $\left(R^{2}=0,915 ; F_{(2,6)}=32,41\right.$; $p<0,0006$; Error of estimate $=1,922$ );

Max (young men profile 2) $=-131,7+2,751 \times$ ar-Go + 1,296 $\times$ S-ar:ar-Go - 0,374 $\times$ N-CC $-0,937$ $\times \mathrm{N}-\mathrm{Se}+0,544 \times \mathrm{N}-\mathrm{S}\left(\mathrm{R}^{2}=0,995 ; \mathrm{F}_{(5,3)}=122,5 ;\right.$ $p<0,0012$; Error of estimate $=0,304)$;

R.asc. (young men profile 2) $=1,353+0,937 \times$ ar-Go $+0,488 \times \mathrm{N}-\mathrm{Se}-0,148 \times \mathrm{N}-\mathrm{S}-\mathrm{Ar}\left(\mathrm{R}^{2}=0,981\right.$; $F_{(3,5)}=85,12 ; p<0,0001$; Error of estimate $\left.=0,620\right)$;

$F($ young men profile 2$)=118,2-0,972 \times \mathrm{N}-\mathrm{CC}$ $+0,443 \times$ ar-Go $\left(R^{2}=0,853 ; F_{(2,6)}=17,40 ; p<0,0032\right.$; Error of estimate $=1,573)$; 
where here and hereafter, S-E (length of the posterior part of the skull base according to Steiner C. C.) is the distance from point $S$ to the structural point E (mm); S-ar:ar-Go (indicator S-ar:ar-Go according to Jarabak J. R.) - indicator of the ratio of distances S-ar and ar-Go; N-S N-S (length of the anterior cranial base by Jarabak J. R.) - the distance from point $\mathrm{N}$ to point $\mathrm{S}(\mathrm{mm})$; $\mathrm{N}-\mathrm{S}-\mathrm{Ar}$ (saddle angle according to Bjork $A$.) is the angle between the anterior cranial base and the lateral cranial base, which determines the position of the temporomandibular joint and glenoid fossae and is formed by the lines N-S and S-ar $\left({ }^{\circ}\right)$.

In young men with 2 facial profiles, the coefficients of determination of the regression equations of angles B, G and I were from 0.398 to 0.592 and therefore have no practical significance for orthodontists. The regression equations of the $\mathrm{MM}$ and $\mathrm{T}$ angles in young men with 2 facial profiles are not constructed at all.

For young men with 3 face profile:

$\mathrm{L}$ Mand (young men profile 3 ) $=30,10+1,158 \times$ $\mathrm{N}-\mathrm{C} \overline{\mathrm{C}}-4,536 \times \mathrm{N}-\mathrm{S}: \mathrm{S}-\operatorname{Ar}\left(\mathrm{R}^{2}=0,958 ; \mathrm{F}_{(2,14)}=161,2 ;\right.$ $\mathrm{p}<0,0000$; Error of estimate $=3,718)$;

Max (young men profile 3) =3,898 - 0,592 $\times$ PPTV + 0,403 $\times$ ar-Go $\left(R^{2}=0,929 ; \quad F_{(2,14)}=91,12 ;\right.$ $\mathrm{p}<0,0000$; Error of estimate $=3,008)$;

R.asc. (young men profile 3 ) $=-20,18+0,796$ $\times$ ar-Go $+1,024 \times$ S-E $+0,502 \times$ POr-NBa $+2,988$ $\times \mathrm{N}-\mathrm{S}: \mathrm{S}-\mathrm{Ar}^{\prime}\left(\mathrm{R}^{2}=0,994 ; \mathrm{F}_{(4,12)}=501,3 ; \mathrm{p}<0,0000 ; \mathrm{Er}-\right.$ ror of estimate $=1,385)$;

where here and hereafter, P-PTV (distance PPTV according to Ricketts R. M.) is the distance from the point $\mathrm{Po}$ to the point $\mathrm{Pt}$, parallel to the Frankfurt plane (mm).

In young men with 3 facial profiles, the coefficients of determination of the regression equations of angles B, G and MM were from 0.295 to 0.375 and therefore have no practical significance for orthodontists. Regression equations of angles $F$, I and $T$ in young men with 3 facial profiles are not constructed at all.

For young women with 1 face profile:

$L_{-}$Mand (young women profile 1) $=3,246+$ $1,01 \overline{3} \times \mathrm{N}-\mathrm{CC}+0,315 \times$ ar-Go $\left(\mathrm{R}^{2}=0,802 ;\right.$ $F_{(2,32)}=64,66 ; p<0,0000$; Error of estimate $\left.=3,656\right)$;

Max (young women profile 1) $=-10,11+0,450$ $\times \mathrm{N}-\mathrm{S}+0,206 \times$ ar-Go $+0,126 \times \mathrm{N}-\mathrm{S}-\mathrm{Ba}$ $\left(R^{2}=0,784 ; F_{(3,31)}=37,52 ; p<0,0000\right.$; Error of estimate $=2,084)$;

R.asc. (young women profile 1) $=19,46+1,498$ $\times \mathrm{S}-\mathrm{ar}+0,453 \times \mathrm{POr}-\mathrm{NBa}+0,224 \times \mathrm{N}-\mathrm{S}-0,511 \times$ S-ar:ar-Go $\left(R^{2}=0,956 ; F_{(4,30)}=161,8 ; p<0,0000\right.$; Error of estimate $=1,597)$;

where here and hereafter, N-S-Ba (angle N-S$\mathrm{Ba}$ according to Bjork A.) is the angle formed by the lines S-N (front part of the skull base) and S-Ba $\left({ }^{\circ}\right)$; S-ar (length of the lateral cranial base according to Jarabak J.R.) is the distance from the point $S$ to the point ar (mm).

In young women with 1 facial profile, the coefficients of determination of the regression equations of angles B, G, MM, F, I and T were from 0.116 to
0.594 and therefore have no practical significance for orthodontists.

For young women with 2 face profile:

$B$ (young women profile 2) $=13,12+0,540 \times S$ ar:ar-Go + 1,206 $\times$ POr-NBa $-0,868 \times \mathrm{N}-\mathrm{S}$ $\left(R^{2}=0,643 ; F_{(3,11)}=6,594 ; p<0,0082 ;\right.$ Error of estimate $=3,259)$;

$\mathrm{G}$ (young women profile 2) $=-32,95+0,797 \times$ S-ar:ar-Go + 0,788 $\times$ N-S-Ba $\left(R^{2}=0,619 ;\right.$ $F_{(2,12)}=9,747 ; p<0,0031$; Error of estimate=3,983);

L_Mand (young women profile 2) $=33,46-$ $0,28 \overline{6} \times$ S-ar:ar-Go + 0,897 $\times \mathrm{N}-\mathrm{Se}\left(\mathrm{R}^{2}=0,687\right.$; $F_{(2,12)}=13,20 ; p<0,0009$; Error of estimate=1,703);

R.asc. (young women profile 2) $=4,999-0,442$ $\times$ S-ar:ar-Go $+1,057 \times \mathrm{N}-\mathrm{S}+0,773 \times \mathrm{S}-\mathrm{E}$ $\left(R^{2}=0,870 ; \quad F_{(3,11)}=24,46 ; p<0,0000\right.$; Error of estimate=1,822);

MM (young women profile 2) $=83,10-1,486 \times$ S-E + 0,416 × ar-Go - 0,514 × P-PTV $\left(R^{2}=0,846\right.$; $F_{(3,11)}=20,14 ; p<0,0001$; Error of estimate=1,409);

$\mathrm{F}($ young women profile 2) $=132,6-1,406 \times \mathrm{S}-\mathrm{E}$ - 0,400 × S-ar:ar-Go + 1,392 × S-ar - 0,586 × N-S $\left(R^{2}=0,687 ; F_{(4,10)}=5,491 ; p<0,0133\right.$; Error of estimate $=2,106)$.

In young women with 2 facial profiles, the coefficients of determination of the regression equations distance Max, as well as angles I and $T$ were from 0.310 to 0.530 and therefore have no practical significance for orthodontists.

For young women with 3 face profile:

L_Mand (young women profile 3) $=-11,54+$ $0,78 \overline{9} \times \mathrm{N}-\mathrm{Se}+0,352 \times \mathrm{ar}-\mathrm{Go}+0,550 \times \mathrm{S}-\mathrm{ar}$ $\left(R^{2}=0,798 ; F_{(3,20)}=26,33 ; p<0,0000\right.$; Error of estimate=3,509);

R.asc. (young women profile 3) $=-27,74+$ $0,662 \times$ ar-Go + 0,699 $\times$ POr-NBa + 0,477 $\times \mathrm{N}-\mathrm{S}+$ $0,404 \times S-E\left(R^{2}=0,939 ; F_{(4,19)}=73,75 ; p<0,0000 ; E r-\right.$ ror of estimate $=1,918)$;

$\mathrm{F}$ (young women profile 3$)=155,2-0,746 \times \mathrm{H}+$ $0,491 \times$ POr-NBa $-0,769 \times \mathrm{N}-\mathrm{CC}+0,467 \times \mathrm{N}-\mathrm{Se}$ $\left(R^{2}=0,748 ; F_{(4,19)}=14,09 ; p<0,0000 ;\right.$ Error of estimate $=2,547)$;

I (young women profile 3) $=152,5-1,098 \times \mathrm{H}+$ $0,865 \times$ POr-NBa - 0,101 $\times$ S-ar:ar-Go + 0,182 $\times$ $\mathrm{N}-\mathrm{S}-\mathrm{Ba}\left(\mathrm{R}^{2}=0,627 ; \mathrm{F}_{(4,19)}=7,970 ; \mathrm{p}<0,0006\right.$; Error of estimate=2,035).

In young women with 3 facial profiles, the coefficients of determination of the regression equations of angles $B, G$ and $M M$, as well as the distance Max were from 0.101 to 0.531 and therefore have no practical significance for orthodontists. The regression equation of the angle $\mathrm{T}$ in young women with 3 facial profiles is not constructed at all.

A number of researchers have simulated teleroentgenographic parameters of craniofacial structures in Ukrainian young men and young women with orthognathic occlusion, which are used in various methods of teleroentgenographic analysis. Thus, regression models of a number of teleroentgenographic indicators of the dental system were created, which should be determined when performing orthodontic treatment of patients, depending on the basic cephalometric indicators by the 
method of Charles J. Burstone [16] (by 6 models out of 14 possible with a coefficient of determination from 0.806 to 0.918 in young men and from 0.510 to 0.768 in young women), according to method of R. M. Ricketts [13] (by 2 models out of 13 possible with a coefficient of determination of 0.884 and 0.928 in young men and 0.735 and 0.719 in young women), according to method of E. P. Harvold [12] (young men -4 models out of 5 possible with a coefficient of determination from 0.616 to 0.940 , and young women -3 models with a coefficient of determination from 0.571 to 0.857 ). At the same time, according to Dmitriev M. O. et al. [14], who performed modeling of gnatometric parameters depending on the parameters of basal cranial structures in Ukrainian adolescents with orthognathic occlusion, in young men from 43 possible regression models built only 4 reliable models with a coefficient of determination greater than 0.5 (for indicators effective length of the upper jaw, the length of the upper jaw, the angle SND and the distance S_L), and in young women - no model with a coefficient of determination greater than 0.5 .

According to the results of our simulation of teleroentgenographic indicators, which were included into the second group according to the Schwarz A. M. method depending on the indicators of the first group in young men with normal occlusion close to orthognathic occlusion and harmonious face with different facial profiles, 10 out of 27 possible reliable regression models with a coefficient of determination greater than $0.6\left(R^{2}=\right.$ from 0.642 to $0.995)$, and in young women with different facial profiles -13 models out of 27 possible $\left(R^{2}=\right.$ from 0.619 to 0.956 ) were build. It should be noted that both young men and young women with different facial profiles according to the method of Schwarz A. M. among the models with a coefficient of determination greater than 0.6 built most models for linear dimensions, included into the second group of indicators - both young men and young women by 7 of 9 possible. Moreover, for the distance R.asc. constructed models with a coefficient of determination greater than 0.6 for both young men of all facial profiles $\left(R^{2}\right.$, respectively, $0.870,0.981$ and $0.994)$ and for young women of all facial profiles $\left(R^{2}\right.$, respectively, $0.956,0.870$ and 0.939$)$, and for the distance $L$ _Mand such models are constructed for young women of all facial profiles $\left(R^{2}\right.$, respectively, 0.802, 0.687 and 0.798$)$ and for young men with the second $\left(R^{2}=0.915\right)$ and third $\left(R^{2}=0.958\right)$ facial profiles.

Also noteworthy are the following indicators, which were included in the second group according to the method of Schwarz A. M.: angle T - in both young men and young women with different facial profiles, or had a coefficient of determination less than 0.310 , or models were not built at all; MM and I angles in young men with different facial profiles, either had a coefficient of determination less than 0.6 , or the models were not built at all.

In young men, the constructed regression equations of teleroentgenographic parameters included into the second group according to the Schwarz A. M. method, most often include the following indicators of the first group: the value of ar-Go distance according to Burstone C. J. (25.8\%), as well as N$\mathrm{CC}$ distances according to Ricketts R. M. and N-Se according to Schwarz A. M. and NS:S-Ar' according to Bjork A. (12.9 \% each).

It should be noted that the N-CC distance, according to other researchers, was also among the indicators of the first group of basic cephalometric parameters, which were most often included into the models of the second group, both young men and young women when use Burstone C. J. [16], Harvold E. P. [12] analysis and was included into all constructed models in young women according to the method of Ricketts R. M. [13].

In young women, the models of teleroentgenographic indicators included into the second group according to the method of Schwarz A. M. the most often include the following indicators of the first group: the value of S-ar:ar-Go according to Jarabak J. R. (17.1\%), the distance NS according to Jarabak J. R. (14.6\%), as well as ar-Go distances according to Burstone C. J. and POr-NBa angle according to Ricketts R. M. (12.2 \% each).

The POr-NBa angle was also one of those cephalometric parameters of the first group, which were the most often included into the models of indicators of the second group in both young women and young men in the analysis according to Burstone C. J. [16] and Harvold E. P. [12].

Also, it should be noted that in young men the models of teleroentgenographic indicators included into the second group according to the method of Schwarz A. M. do not include the distance S-ar according to Jarabak J. R. and the angle N-S-Ba according to Bjork A.; and for young women, the angle N-S-Ar according to Bjork $A$. and the index N-S: S-Ar' according to Bjork $A$.

In our opinion, such an approach to determining the appropriate teleroentgenographic indicators for early diagnosis and subsequent correction of pathological changes of the dental apparatus, which takes into account the age, sex and features of the patient's face, meets modern requirements in orthopedic, orthodontic, surgical practice, when the doctor needs to determine the most individualized, adapted to a particular patient method and scope of medical care.

\section{Conclusions}

For Ukrainian young men and young women with different facial profiles according to Schwarz A. M. with normal occlusion close to orthognathic occlusion and a harmonious face, regression models of teleroentgenographic parameters, which can be corrected during surgery ( 2 group of indicators) depending on usually unchanged parameters (1 group of indicators) were constructed: in young men, 10 of the 27 possible reliable regression models with a coefficient of determination greater than $0.6\left(R^{2}=\right.$ від 0,642 до 0,995$)$ were constructed, and in young women -13 models from 27 possible $\left(R^{2}=\right.$ від 0,619 до 0,956). 
Both for young men and young women, the most models of indicators of the second group are built for linear dimensions - both young men and young women have 7 models from 9 possible each. The constructed regression equations most often include the following indicators of the first group: in young men - ar-Go distances according to Burstone C. J., N-CC according to Ricketts R. M., $\mathrm{N}-\mathrm{Se}$ according to Schwarz A. M. and indicator NS:S-Ar' according to Bjork A.; in young women - indicator S-ar:ar-Go according to Jarabak J. R., distances N-S according to Jarabak J. R. and ar-Go according to Burstone C. J. and angle POr-NBa according to Ricketts R. M.

\section{Prospects for further research}

The prospect of further research is the modeling of teleroentgenographic indicators of the position of teeth and the profile of soft tissues of the face characteristic of the inhabitants of Ukraine with orthognathic occlusion of different age and sex groups, taking into account the profile of their face.

\section{Список літератури}

1. Дмітрієв МО. Кореляції основних краніальних показників з характеристиками верхньої та нижньої щелеп у мешканців України юнацького віку. Світ медицини та біології. 2016;4(58):24-9.

2. Дмітрієв МО. Зв'язки основних краніальних показників з характеристиками положення зубів верхньої і нижньої щелеп та профрілем м'яких тканин обличчя в юнаків і дівчат. Вісник морфології. 2017;23(1):125-31.

3. Дорошенко СИ, Кульгинский ЕА. Основы телерентгенографии. К., Здоров'я; 2007. 72 с.

4. Мороз ВМ, Гунас IB, Дмітрієв МО, Прокопенко ОС. Кореляції лінійних показників нижньої щелепи з характеристиками положення зубів та профрілю м'яких тканин лиця у мешканців України юнацького віку. Biomedical and Biosocial Anthropology. 2016;27:81-8.

5. Alshammery DA, Almubarak S, Hezaim AB, Alkhunein R, Pani SC, Mossadomi H. Cephalometric norms of skeletal relationship among populations in selected Arab countries: A systematic review and meta-analysis. Saudi Journal of Oral Sciences. 2016;3(2):69-74. doi: 10.4103/1658-6816.188079.

6. Amini F, Razavian ZS, Rakhshan V. Soft tissue cephalometric norms of Iranian class I adults with good occlusions and balanced faces. International orthodontics. 2016;14(1):108-22.

7. Atit MB, Deshmukh SV, Rahalkar J, Subramanian V, Naik C, Darda M. Mean values of Steiner, Tweed, Ricketts and McNamara analysis in Maratha ethnic population: A cephalometric study. APOS Trends in Orthodontics. 2013;3(5):137-51. doi: 10.4103/2321-1407.119095.

8. Behbehani F, Hicks EP, Beeman C, Kluemper GT, Rayens MK. Racial variations in cephalometric analysis between Whites and Kuwaitis. Angle Orthod. 2006;76(3):406-11. doi: 10.1043/00033219(2006)076[0406:RVICAB]2.0.CO;2

9. Björk A. Sutural growth of the upper face studied by the implant method. Acta Odontologica Scandinavica. 1966;24(2):109-27.
10. Burstone CJ. Lip posture and its significance in treatment planning. Am. J. Orthod. 1967;53(4):26284.

11. Castillo JC, Gianneschi G, Azer D, et al. The relationship between 3D dentofacial photogrammetry measurements and traditional cephalometric measurements. The Angle Orthodontist. 2019;89(2):27583. doi: 10.2319/120317-825.1.

12. Chernysh AV, Hasiuk PA, Yasko VV, Smolko DG. Regression models of individual cephalometric indicators used in the method of E. P. Harvold. Вісник морфології. 2018;24(4):29-34.

13. Chernysh AV. Regression models of individual cephalometric indicators used in the method of R. M. Ricketts. Biomedical and Biosocial Anthropology. 2018;32:56-62.

14. Dmitriev MO, Dudik OP, Chugu TV, Cherkasova OV. Modeling of gnatometric indices depending on parameters of basal cranial structures in boys and girls with orthognathic bite. Вісник наукових досліджень. 2018;1(90):110-3.

15. Gueye M, Dieng L, Mbodj EB, Seck AK, Toure A, Thioune N, Ngom PI. Relationship between bizygomatic width and the size of maxillary anterior teeth among young Senegalese black people recruited in army. Odontostomatol. Trop. 2014;37(148):5-12.

16. Gunas IV, Chernysh AV, Cherkasov VG, Cherkasova OV. Modeling by using regression analysis of teleroentgenographic individual indicators used in the method of Charles J. Burstone. Biomedical and Biosocial Anthropology. 2018;31:59-65.

17. Hashim HA, AIBarakati SF. Cephalometric soft tissue profile analysis between two different ethnic groups: a comparative study. J Contemp Dent Pract. 2003;4(2):60-73.

18. Jacobson A, White L. Radiographic cephalometry: from basics to 3-D imaging. American Journal of Orthodontics and Dentofacial Orthopedics. 2007;131(4):215-22.

19. Jarabak JR., Fizzell JA. Technique and treatment with light-wire edgewise appliances, ed. 2, St. Louis. The CV Mosby Company; 1972. 635 p.

20. Johannsdottir B, Thordarson A, Magnusson TE. Craniofacial skeletal and soft tissue morphology in Icelandic adults. European Journal of Orthodontics. 2004;26:245-50. doi: 10.1093/ejo/26.3.245.

21. Kilic N, Catal G, Oktay H. McNamara norms for Turkish adolescents with balanced faces and normal occlusion. Aust. Orthod. J. 2010;26(1):33-7.

22. Mohammad HA, Abu Hassan MI, Hussain SF. Academic Journals Cephalometric evaluation for Malaysian Malay by Steiner analysis. Scientific Research and Essays. 2011;6(3):627-34. doi: 10.5897/SRE10.869.

23. Phulari B. An atlas on cephalometric landmarks. JP Medical Ltd; 2013. 230 p.

24. Ricketts RM. Cephalometric analysis and synthesis. The Angle Orthodontist. 1961;31(3):141-56.

25. Schwarz AM. Roentgenostatics: a practical evaluation of the x-ray headplate. American Journal of Orthodontics. 1961;47(8):561-85.

26. Schwarz AM. Röntgenostatics; Practical Evaluation of the Tele-X-ray-photo (study-head-plate) (Vol. 1). Leo L. Bruder; 1960. 48 p.

27. Steiner CC. Cephalometrics in clinical practice. Angle Orthod.. 1959;29:8-29. 


\section{References}

1. Dmitriev MO. Koreliatsii osnovnykh kranialnykh pokaznykiv z kharakterystykamy verkhnoi ta nyzhnoi shchelep u meshkantsiv Ukrainy yunatskoho viku. Svit medytsyny ta biolohii. 2016;4(58):24-9. (Ukrainian).

2. Dmitriev MO. Zviazky osnovnykh kranialnykh pokaznykiv z kharakterystykamy polozhennia zubiv verkhnoi i nyzhnoi shchelep ta profilem miakykh tkanyn oblychchia $v$ yunakiv i divchat. Visnyk morfolohii. 2017;23(1):125-31. (Ukrainian).

3. Doroshenko SI, Kulginskii EA. Osnovy telerentgenografii. K., Zdorov'ya; 2007. 72 s. (Russian).

4. Moroz VM, Gunas IV, Dmitriev MO, Prokopenko OS. Koreliatsii liniinykh pokaznykiv nyzhnoi shchelepy z kharakterystykamy polozhennia zubiv ta profiliu miakykh tkanyn lytsia u meshkantsiv Ukrainy yunatskoho viku. Biomedical and Biosocial Anthropology. 2016;27:81-8. (Ukrainian).

5. Alshammery DA, Almubarak S, Hezaim AB, Alkhunein R, Pani SC, Mossadomi H. Cephalometric norms of skeletal relationship among populations in selected Arab countries: A systematic review and meta-analysis. Saudi Journal of Oral Sciences. 2016;3(2):69-74. doi: 10.4103/1658-6816.188079.

6. Amini F, Razavian ZS, Rakhshan V. Soft tissue cephalometric norms of Iranian class I adults with good occlusions and balanced faces. International orthodontics. 2016;14(1):108-22.

7. Atit MB, Deshmukh SV, Rahalkar J, Subramanian V, Naik C, Darda M. Mean values of Steiner, Tweed, Ricketts and McNamara analysis in Maratha ethnic population: A cephalometric study. APOS Trends in Orthodontics. 2013;3(5):137-51. doi: 10.4103/2321-1407.119095.

8. Behbehani F, Hicks EP, Beeman C, Kluemper GT, Rayens MK. Racial variations in cephalometric analysis between Whites and Kuwaitis. Angle Orthod. 2006;76(3):406-11. doi: 10.1043/00033219(2006)076[0406:RVICAB]2.0.CO;2.

9. Björk A. Sutural growth of the upper face studied by the implant method. Acta Odontologica Scandinavica. 1966;24(2):109-27.

10. Burstone CJ. Lip posture and its significance in treatment planning. Am. J. Orthod. 1967;53(4):26284.

11. Castillo JC, Gianneschi G, Azer D, et al. The relationship between 3D dentofacial photogrammetry measurements and traditional cephalometric measurements. The Angle Orthodontist. 2019;89(2):27583. doi: 10.2319/120317-825.1.

12. Chernysh AV, Hasiuk PA, Yasko VV, Smolko DG. Regression models of individual cephalometric indicators used in the method of E. P. Harvold. Visnyk morfolohii. 2018;24(4):29-34.
13. Chernysh AV. Regression models of individual cephalometric indicators used in the method of R. M. Ricketts. Biomedical and Biosocial Anthropology. 2018;32:56-62.

14. Dmitriev MO, Dudik OP, Chugu TV, Cherkasova OV. Modeling of gnatometric indices depending on parameters of basal cranial structures in boys and girls with orthognathic bite. Visnyk naukovykh doslidzhen. 2018;1(90):110-3.

15. Gueye M, Dieng L, Mbodj EB, Seck AK, Toure A, Thioune N, Ngom Pl. Relationship between bizygomatic width and the size of maxillary anterior teeth among young Senegalese black people recruited in army. Odontostomatol. Trop. 2014;37(148):5-12.

16. Gunas IV, Chernysh AV, Cherkasov VG, Cherkasova OV. Modeling by using regression analysis of teleroentgenographic individual indicators used in the method of Charles J. Burstone. Biomedical and Biosocial Anthropology. 2018;31:59-65.

17. Hashim HA, AlBarakati SF. Cephalometric soft tissue profile analysis between two different ethnic groups: a comparative study. J Contemp Dent Pract. 2003;4(2):60-73.

18. Jacobson A, White L. Radiographic cephalometry: from basics to 3-D imaging. American Journal of Orthodontics and Dentofacial Orthopedics. 2007;131(4):215-22.

19. Jarabak JR, Fizzell JA. Technique and treatment with light-wire edgewise appliances, ed. 2, St. Louis. The CV Mosby Company; 1972. 635 p.

20. Johannsdottir B, Thordarson A, Magnusson TE. Craniofacial skeletal and soft tissue morphology in Icelandic adults. European Journal of Orthodontics. 2004;26:245-50. doi: 10.1093/ejo/26.3.245.

21. Kilic N, Catal G, Oktay $\mathrm{H}$. McNamara norms for Turkish adolescents with balanced faces and normal occlusion. Aust. Orthod. J. 2010;26(1):33-7.

22. Mohammad HA, Abu Hassan MI, Hussain SF. Academic Journals Cephalometric evaluation for Malaysian Malay by Steiner analysis. Scientific Research and Essays. 2011;6(3):627-34. doi: 10.5897/SRE10.869.

23. Phulari B. An atlas on cephalometric landmarks. JP Medical Ltd; 2013. 230 p.

24. Ricketts RM. Cephalometric analysis and synthesis. The Angle Orthodontist. 1961;31(3):141-56.

25. Schwarz AM. Roentgenostatics: a practical evaluation of the x-ray headplate. American Journal of Orthodontics. 1961;47(8):561-85.

26. Schwarz AM. Röntgenostatics; Practical Evaluation of the Tele-X-ray-photo (study-head-plate) (Vol. 1). Leo L. Bruder; 1960.48 p.

27. Steiner CC. Cephalometrics in clinical practice. Angle Orthod.. 1959;29:8-29.

\section{Стаття надійшла:} 20.04.2021 p.

\section{Summary}

For Ukrainian young men and young women with different facial profiles according to Schwarz A. M. with normal occlusion close to orthognathic occlusion and a harmonious face, regression models of teleroentgenographic parameters, which can be corrected during surgery (2 group of indicators) depending on the parameters that usually do not change (1 group of indicators) were constructed and analyzed.

In young men, 10 of 27 possible reliable regression models with a coefficient of determination greater than 0.6 $\left(R^{2}=\right.$ from 0,642 to 0,995$)$ were constructed, and in young women -13 models from 27 possible $\left(R^{2}=\right.$ from 0,619 to 0,956 ). Both for young men and young women, the most models of indicators of the second group are built for linear dimensions - both young men and young women have 7 models from 9 possible each. 
The constructed regression equations of teleroentgenographic indicators included into the second group according to the Schwarz A. M. method the most often comprise the following indicators of the first group: in young men - ar-Go distances according to Burstone C. J., N-CC according to Ricketts R. M., N-Se according to Schwarz A. M. and indicator N-S:S-Ar' according to Bjork A.; in young women - indicator S-ar:ar-Go according to Jarabak J. R., distances N-S according to Jarabak J. R. and ar-Go according to Burstone C. J. and angle POr-NBa according to Ricketts R. M.

Key words: lateral teleroentgenography, juvenile age, face profiles by Schwarz, regression models, cephalometric indices.

\section{Резюме}

Одне з актуальних завдань сучасної стоматології - це встановлення належних значень телерентгенографічних показників з урахуванням віку, статі, етнічних і популяційних особливостей, індивідуальних особливостей обличчя пацієнта, для оцінки стану зубощелепного аппарату, вчасної діагностики його патологічних відхилень та їх ефективної корекції.

Мета роботи - побудувати і проаналізувати регресійні моделі телерентгенографрічних показників, які можуть корегуватися під час хірургічних втручань залежно від параметрів, які зазвичай не змінюються в українських юнаків і дівчат із різними профілями обличчя (за Schwarz A.M.), із нормальною оклюзією, наближеною до ортогнатичного прикусу, і гармонійним обличчям.

Дослідили бокові телерентгенограми голови в 49 юнаків віком від 17 до 21 року і 76 дівчат віком від 16 до 20 років із фрізіологічним прикусом, із різними профілями обличчя за Schwarz A.M. Методом регресійного аналізу будували моделі ТРГ-показників, визначення яких найбільш часто орієнтуються під час хірургічних втручань у стоматології, залежно від базових цефалометричних показників (ліцензійний пакет «Statistica 6,0»).

Для юнаків із 1 профрілем обличчя (задній профріль обличчя за Schwarz A.M.) побудовані регресійні моделі для показників: базального кута $\mathrm{B}\left(\mathrm{R}^{2}=0,642 ; \mathrm{F}_{(3,19)}=11,36 ; \mathrm{p}<0,001\right)$, гоніального кута $\mathrm{G}$ $\left(R^{2}=0,742 ; \quad F_{(4,18)}=12,94 ; \quad p<0,001\right)$, довжини гілки нижньої щелепи R.asc. $\left(R^{2}=0,870 ; \quad F_{(4,18)}=30,11\right.$; $p<0,001)$. Для юнаків із 2 профрілем обличчя (прямий профріль обличчя за Schwarz A.M.): довжини нижньої щелепи L_Mand $\left(R^{2}=0,915 ; F_{(2,6)}=32,41 ; p<0,001\right)$, довжини верхньої щелепи Max $\left(R^{2}=0,995\right.$; $\left.F_{(5,3)}=122,5 ; p<0,01\right)$, довжини гілки нижньої щелепи R.asc. $\left(R^{2}=0,981 ; F_{(3,5)}=85,12 ; p<0,001\right)$, лицевого кута $F\left(R^{2}=0,853 ; F_{(2,6)}=17,40 ; p<0,01\right)$. Для юнаків із 3 профрілем обличчя (передній профріль обличчя за Schwarz A.M.): довжини нижньої щелепи $L$ _Mand $\left(R^{2}=0,958 ; F_{(2,14)}=161,2 ; p<0,001\right)$, довжини верхньої щелепи Max $\left(R^{2}=0,929 ; \quad F_{(2,14)}=91,12 ; p<0,001\right)$, довжини гілки нижньої щелепи R.asc. $\left(R^{2}=0,994\right.$; $\left.\mathrm{F}_{(4,12)}=501,3 ; p<0,001\right)$. Для дівчат із 1 профрілем обличчя побудовані моделі для показників: довжини нижньої щелепи L_Mand $\left(R^{2}=0,802 ; \mathrm{F}_{(2,32)}=64,66 ; p<0,001\right)$, довжини верхньої щелепи $\operatorname{Max}\left(R^{2}=0,784\right.$; $\left.\mathrm{F}_{(3,31)}=37,52 ; p<0,001\right)$, довжини гілки нижньої щелепи R.asc. $\left(R^{2}=0,956 ; F_{(4,30)}=161,8 ; p<0,001\right)$. Для дівчат із 2 профілем обличчя: базального кута $B\left(R^{2}=0,643 ; F_{(3,11)}=6,594 ; p<0,01\right)$, гоніального кута $G$ $\left(R^{2}=0,619 ; F_{(2,12)}=9,747 ; p<0,01\right)$, довжини нижньої щелепи $L \_M a n d\left(R^{2}=0,687 ; F_{(2,12)}=13,20 ; p<0,001\right)$, довжини гілки нижньої щелепи R.asc. $\left(R^{2}=0,870 ; \quad F_{(3,11)}=24,46 ; p<0,001\right)$, міжщелепного кута ММ $\left(R^{2}=0,846 ; F_{(3,11)}=20,14 ; p<0,001\right)$, лицевого кута $F\left(R^{2}=0,748 ; F_{(4,19)}=14,09 ; p<0,001\right)$ та інклінаційного кута I $\left(R^{2}=0,627 ; F_{(4,19)}=7,970 ; p<0,001\right)$. Для дівчат із 3 профрілем обличчя: довжини нижньої щелепи L_Mand $\left(R^{2}=0,798 ; F_{(3,20)}=26,33 ; p<0,001\right)$, довжини гілки нижньої щелепи R.asc. $\left(R^{2}=0,939 ; F_{(4,19)}=73,75\right.$; $p<0,001)$, лицевого кута $F\left(R^{2}=0,748 ; \quad F_{(4,19)}=14,09 ; p<0,001\right)$ та інклінаційного кута I $\quad\left(R^{2}=0,627\right.$; $\mathrm{F}_{(4,19)}=7,970 ; p<0,001$.

Отже, в юнаків побудовано 10 із 27 можливих достовірних регресійних моделей із коефріцієнтом детермінації більше 0,6 ( $R^{2}=$ від 0,642 до 0,995), а в дівчат - 13 моделей із 27 можливих $\left(R^{2}=\right.$ від 0,619 до 0,956). І в юнаків, і в дівчат більшість моделей показників другої групи побудовано для лінійних розмірів - і в юнаків, і в дівчат є 7 моделей із 9 можливих. Побудовані рівняння регресії найчастіше включають такі показники першої групи: в юнаків - відстані ar-Go за Burstone C. J., N-CC за Ricketts R. M., N-Se за Schwarz A. M. і показник N-S:S-Ar' за Bjork A.; у дівчат - показник S-ar:ar-Go за Jarabak J. R., відстані N-S за Jarabak J. R. i ar-Go за Burstone C. J. і кут POr-NBa за Ricketts R. M.

Перспектива подальших досліджень - моделювання телерентгенографічних показників положення зубів і профрілю м'яких тканин обличчя, характерних для жителів України з ортогнатичним прикусом різних вікових і статевих груп, з урахуванням профілю обличчя.

Ключові слова: бокова телерентгенографрія, юнацький вік, профілі обличчя за Schwarz, регресійні моделі, цефалометричні показники. 